\title{
Identifying opportunities to improve governance of aquatic agricultural systems through participatory action research
}

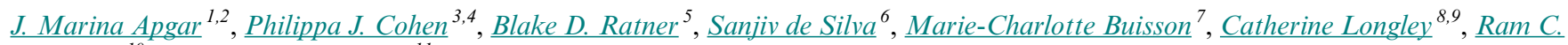 \\ Bastakoti $^{10}$ and Everisto Mapedza ${ }^{11}$
}

\begin{abstract}
Challenges of governance often constitute critical obstacles to efforts to equitably improve livelihoods in social-ecological systems. Yet, just as often, these challenges go unspoken, or are viewed as fixed parts of the context, beyond the scope of influence of agricultural, development, or natural resource management initiatives. What does it take to get governance obstacles and opportunities out in the open, creating the space for constructive dialogue and collective action that can help to address them? We respond to this question by comparing experiences of participatory action research (PAR) in coastal and floodplain systems in four countries (Zambia, Solomon Islands, Bangladesh, and Cambodia) with a focus on understanding how to build more equitable governance arrangements. We found that governance improvement was often an implicit or secondary objective of initiatives that initially sought to address more technical natural resource or livelihood-related development challenges. We argue that using PAR principles of ownership, equity, shared analysis, and feedback built trust and helped to identify and act upon opportunities to address more difficult-to-shift dimensions of governance particularly in terms of stakeholder representation, distribution of authority, and accountability. Our findings suggest that the engaged and embedded approach of researcher-facilitators can help move from identifying opportunities for governance change to supporting stakeholders as they build more equitable governance arrangements.
\end{abstract}

Key Words: aquatic agricultural systems; equity; facilitation; governance; participatory action research; representation; transformation

\section{INTRODUCTION}

In Africa, Asia, and the Pacific approximately 500 million people live in and depend on aquatic agricultural systems (AAS); approximately 138 million of those people live in poverty (C. Béné and S. J. Teoh, unpublished data). AAS are social-ecological systems in floodplains, deltas, and coasts where people's wellbeing is tightly linked to agricultural and fisheries productivity. AAS support food and income provision, but as local and global demands and pressures on resources increase, these systems are challenged to support both greater and more equitable productivity, income generation, and nutrition benefits. The current status of many AAS is illustrative of a governance crisis, where natural environments are degrading, people remain highly dependent on those environments, and the inequitable distribution of environmental costs and benefits perpetuates poverty (Barret et al. 2011). Addressing this crisis, and realizing improved productivity and more equitable outcomes in these systems, is a major challenge to global development commitments, such as the achievement of the sustainable development goals concerned with poverty, food security, nutrition, and environmental management (Griggs et al. 2013).

There is now mainstream recognition that those who rely on AAS should be engaged in their governance, and in adjusting governance in response to inevitable change (Pomeroy 1995, Berkes 2009). This sentiment is broadly captured by the concepts of adaptive comanagement (Armitage et al. 2009) or cogovernance (Kooiman et al. 2005). Cogovernance inherently encourages multistakeholder platforms for deliberation and action. Cogovernance can be responsive to localized and rapid changes, and consequently it is argued, it is well suited for governing highly diverse and dynamic social-ecological systems such as AAS (Song et al. 2013). In reviewing cases of cogovernance of fisheries, Evans et al. (2011) and Cinner et al. (2012) found that in some cases cogovernance had led to ecological improvements and increases in dimensions of human well-being. They also found, however, that, even irrespective of ecological impacts, cogovernance does not necessarily address issues of inequality in processes or outcomes, and can at times reinforce existing inequalities (Ribot 1999, Béné 2009, Cinner et al. 2012). Participation and equity are valued principals within cogovernance, therefore, understanding the governance context, and the performance of cogovernance, must include an appreciation of who holds the authority to govern, whose interests are being represented, and to whom and for what objectives are governors being held accountable.

Researchers focused on governance in social-ecological systems have developed a number of frameworks, including interactive governance (Kooiman et al. 2008, Bavinck et al. 2013), and institutional analysis and development (IAD framework; Ostrom 2005, 2009), useful for understanding the performance and potential of collaborative forms of governance. These frameworks encourage the analysis of a number of dimensions of governance systems across scales. Further, to consider how governance might "fit" or perform, they prompt analysis of the "system to be governed" (sensu Kooiman et al. 2008), including characteristics of the user groups and the resource system in focus. Ratner et al. (2013a) adapted the IAD framework specifically to examine collective action as a means to manage resource

\footnotetext{
${ }^{1}$ formerly WorldFish, Penang, Malaysia, ${ }^{2}$ currently Institute of Development Studies, Brighton, UK, ${ }^{3}$ WorldFish, Honiara, Solomon Islands, ${ }^{4}$ ARC Centre of Excellence for Coral Reef Studies, James Cook University, Townsville, Australia, ${ }^{5}$ WorldFish, Penang, Malaysia, ${ }^{6}$ International Water Management Institute, Colombo, Sri Lanka, ${ }^{7}$ International Water Management Institute, New-Delhi, India, ${ }^{8}$ formerly WorldFish, Lusaka, Zambia, ${ }^{9}$ currently Independent Consultant, ${ }^{10}$ International Water Management Institute, Kathmandu, Nepal, ${ }^{11}$ International Water Management Institute, Pretoria, South Africa
} 
competition. Application of this adapted framework is intended to identify distinct points for intervention or engagement that offer potential for catalyzing improvements to socioeconomic and environmental conditions, as well as supporting transitions or transformations in the governance context. These promising points for engagement might be considered analogies for "windows of opportunity" (sensu Olsson et al. 2006). Moreover, the adapted IAD framework explicitly acknowledges that there will be feedback between outcomes realized and the emergence of further opportunities for change to be tackled within the action arena. This presents an interactional view of the process that leads to stakeholders improving governance. In a subsequent paper, Ratner et al. (2013b) propose a framework that prioritizes a deeper understanding of equity within, rather than simply as a function of, a governance system by calling the analysts' attention to social differentiation within three dimensions: stakeholder representation, distribution of authority, and mechanisms of accountability. This framework elaborates a process and equity-focused understanding of the governance context.

The application of these frameworks has primarily focused on expost explanation of differences in outcomes, e.g., resource status or distribution of costs and benefits, as opposed to analysis undertaken with stakeholders at more formative stages of designing interventions, where there is a chance to shape the choice of desired outcomes and strategies to achieve those. A practical challenge remains, therefore, in translating these broad observations about opportunities for governance improvement into actions that catalyze commitments to change drawing on stakeholders' multiple perspectives and objectives. This requires the combination of a suitably flexible and accessible framework that can inform equally flexible forms of engagement with stakeholders. Ratner et al. (2013b) propose that their framework is particularly well tailored for use within a participatory action research (PAR) approach. PAR aims to bring research and action together through codevelopment of goals and lines of enquiry, and facilitated reflection and learning processes with stakeholders (e.g., Reason and Bradbury 2008). This paper is the first attempt to test this proposition through extended engagements and a comparative case study approach.

We reflect on the practical challenge of how to move from assessing the key dimension of governance in social-ecological systems to fostering governance change. To do so, we examine the implementation of a multicountry and multipartner agricultural research program implementing PAR in AAS. Specifically, in four case studies we paired PAR with a governance assessment using the Ratner et al. (2013b) framework, chosen for its flexibility and simplicity. This understanding of the governance landscape created a platform to collaboratively understand, and then to pursue opportunities for change in the social-ecological system, including the governance context. Each case illustrates comanagement in a variety of forms and contexts. For each case we ask the following: In what ways has the use of PAR enabled local stakeholders to identify and pursue opportunities for governance improvement?

In answering this question, we draw on two particular elements from the Ratner et al. (2013a) framework. First, we consider that it is within the action arena that there are opportunities for PAR to contribute to socioeconomic and governance change, outcomes, or transitions, which we consider as windows of opportunity. Second, we shine an analytical light on the idea of feedbacks between preliminary outcomes, the action arena, and subsequent outcomes. In contrast to previous uses of these frameworks, we concentrate less on presenting a comprehensive description of the governance systems and the action arena, and focus more on analyzing the processes of engagement that responded and contributed to early signs of change.

\section{ENGAGING THROUGH PARTICIPATORY ACTION RESEARCH}

Many decentralized development initiatives seek to work with local governance structures and simultaneously challenge them, i.e., to promote more equitable distribution of power, improve accountability, and broaden participation; in practice, however, these two objectives can be difficult to reconcile (Ribot 1999, Béné et al. 2009). Improving representation and accountability as well as fostering a more equitable distribution of authority in cogovernance initiatives, therefore, requires that they move beyond technical fixes and move toward engaging with and transforming underlying institutional inequalities (Adger et al. 2005, Pelling 2010, Kabeer 2012, McDougall and Banjade 2015). This remains a practical challenge for those espousing to support more equitable outcomes through cogovernance.

Researchers engaged in adaptive cogovernance initiatives (e.g., Ojha et al. 2013) focus on learning as a mechanism to support stakeholders to navigate ongoing change and uncertainty (PahlWostl 2009, Pahl-Wostl et al. 2007, 2010). They do so through using various participatory approaches. PAR is used in many practitioner fields leading to a diversity of applications (e.g., Reason and Bradbury 2008). In addition to being action-oriented and participatory, common characteristics of the approach include being values-based and using iterative learning principles (Popplewell and Hayman 2012). Multistakeholder groups, including researchers, use PAR to move through cycles of planning, acting, observing, and reflecting, ensuring that learning is systematic. The few documented accounts of the practical use of PAR to enable improvements in resource governance indicate that substantial challenges remain in building institutional and researcher commitment to the approach (Colfer et al. 2011, Ojha et al. 2013). Although there is considerable analysis on the processes of change and learning in social-ecological systems (e. g., Olsson et al 2006, Westley et al. 2011, 2013), few analyses focus specifically on how participatory approaches used by researcherfacilitators may catalyze governance improvements within socialecological systems, or whether and if so how, they support engagement with and transformation of underlying power dynamics.

We extend this emerging field of practice and research by sharing learning from the CGIAR Research Program on Aquatic Agricultural Systems (CRP AAS). This large, multipartner program was implemented during 2012-2015 in sites selected as representative of major AAS with high levels of poor people dependent upon them for their livelihoods. We examine four cases, one located in African inland water systems (Barotse Floodplain in Zambia); two in Asian mega-deltas (Southern Polder Zone of Bangladesh and the Tonle Sap Floodplain in Cambodia); and one in marine and coastal systems of the coral triangle (Malaita and Western Provinces in the Solomon Islands; AAS 2011). 
The program committed to four guiding principles applying PAR (see Apgar and Douthwaite 2013): (i) ownership: the process is owned by participants who define their goals; (ii) equity: facilitators recognize power relations and are mindful of who is participating and how; (iii) shared analysis: resulting data are analyzed jointly; and (iv) feedback: results are fed back into ongoing development processes. The engagement strategies used in each site deliberately embraced participation in technical solutions and collective action arenas, moving beyond superficial use of participatory tools (e.g., Kesby 2005), and emphasizing researchers as embedded in complex systems (Phelps and Hase 2002, Burns 2007). Within this systems perspective, we consider positive conditions in action arenas to be analogous to "windows of opportunity" in representing the convergence of three circumstances: a problem emerges, a contextually appropriate solution is possible, and the political climate is favorable (Kingdon 1995, Olsson et al. 2006). In this view, changes in governance cannot be planned but rather must be navigated according to emerging opportunities (Olsson et al. 2006, 2008, Biggs et al. 2010, Meijerink and Huitema 2010). Although these may be difficult to predict, the CRP AAS hypothesized that improving stakeholders' ability to identify such opportunities in real time would better enable them to navigate them. Recognizing that addressing development objectives in complex systems requires multiscale governance arrangements (Lebel et al. 2006, Biggs et al. 2010, 2015), the analysis and pursuit of opportunities for change considered, wherever possible, interactions across scales of the AAS.

\section{CASE STUDIES AND METHODS}

We used a case study methodology to surface learning across CRP AAS sites that engaged with governance challenges (Yin 2009). Reflecting the PAR approach, we actively codesigned initiatives, including the research elements, with stakeholders to help them address concerns and questions relating to their real-life challenges (Reason and Bradbury 2008). This approach does not conform to research studies that test predefined hypotheses with survey instruments, experiments, and control groups. However, the approach does yield a rich understanding of change in context. The selection of the sites was purposive (Patton 1990). In selecting sites in which to engage, the program employed criteria such as the quality of prior partnerships and the receptivity of government policy (Whyte 1984, AAS 2013). Among these, the four sites (Table 1A) we selected for in-depth case study analysis in this paper are those with the richest data sets for the full period of program implementation (2012-2015).

The PAR process and evaluation data used for analysis were gathered from documentation of activities implemented with NGOs, traditional authorities, government agencies, etc. (henceforth "system level stakeholders") and community members in selected localities. Activities included participatory visioning, planning, and reflection meetings, focus group discussions, and participant observations. The activities were designed to achieve an agreed common goal with joint plans of action through implementation of research initiatives around priorities linked to community-led interventions. Facilitated reflection and learning events then lead to further rounds of planning and new actions. Research and facilitation teams came together periodically to reflect upon their own practice and experience with the PAR principles, to draw out first and second person learning, a method used often by action researchers (e.g., Reason and Torbert 2001). These data represent the consolidation of knowledge of coauthors as locally engaged researcherfacilitators. In addition, we draw on evidence from other studies in these sites that provide context to the findings on prior governance arrangements, processes, and changes (e.g., Resurreccion 2006, Middleton and Tola 2008, Keskinen and Sithirith 2009, Cohen et al. 2012, Keskinen and Varis 2012, Gain and Schwab, 2012, Benson et al. 2015, Cohen and Steenbergen 2015). Douthwaite et al. (2015) provide a comprehensive account of learning from PAR implementation in CRP AAS including how joint ownership by communities and system level stakeholders led to more inclusive science. In this paper we draw illustrative examples from the four cases with a particular focus on governance improvement and processes that support governance transformations.

\section{RESULTS}

Given the relatively early stage of implementation of these PAR initiatives, we have framed the analysis as a journey of improving governance that we were a part of rather than a destination. The starting point of the governance context is shown in Table $1 \mathrm{~B}$. We organize our results into three key areas of learning: (i) using PAR with stakeholders to identify and pursue windows of opportunity for governance change, (ii) the facilitation challenges of building equity into the PAR process to enable more inclusive governance outcomes, and (iii) engaging across scales to influence the political climate beyond a specific locality. In each section we present illustrative examples from the four cases.

\section{Recognizing and pursuing windows of opportunity for governance change}

In all four cases we find that windows of opportunity for bringing about change in the governance context were two-tiered (Table 2). Initially, stakeholders focused on collectively addressing the more concrete or technical aspects of the challenges they faced, such as sustaining or increasing productivity of farming and fishing. As time went on, we found that the application of PAR principles (in particular joint ownership of research and action, and joint reflection) facilitated a collective and deeper, more critical assessment of underlying institutional constraints that had not been made explicit or were not evident at the start. The results of this assessment opened up an opportunity for collective action around governance challenges, alongside ongoing technical interventions. Evidence from each of our four cases illustrates that this second-tier opportunity emerged later in the engagement process. Researcher-facilitators observed that this occurred at a stage where trust, meaningful collaboration, and evidence of commitment had been built through joint action toward the specific, more technical, and collectively identified challenges. The timeframes and the lag before the second-tier opportunity emerged differed between cases. For example, a long history of work on comanagement (the technical solution) in Solomon Islands meant a window of opportunity for governance change was quickly opened, whereas in Cambodia the technical interventions were more recent and novel. We provide further detailed evidence from two cases.

In the Southern Bangladesh Polder Zone, system level stakeholders included men, women, and youth representatives from 16 communities. They collectively identified opportunities 
Table 1. (A) The social-ecological system of focus in each case study site. (B) The governance context and the emerging or preparatory signs of transformation.

\begin{tabular}{|c|c|c|c|c|}
\hline \multirow[t]{2}{*}{$\overline{\text { Case }}$} & \multirow[t]{2}{*}{ A. Social-ecological context } & \multicolumn{3}{|c|}{ B. Governance context } \\
\hline & & Stakeholder Representation & Distribution of Authority & Mechanisms of Accountability \\
\hline $\begin{array}{l}\text { Malaita } \\
\text { and } \\
\text { Western } \\
\text { Province } \\
\text { Solomon } \\
\text { Islands }\end{array}$ & $\begin{array}{l}\text { Remote Pacific coastal marine } \\
\text { system with limited access to } \\
\text { infrastructure and support } \\
\text { services. High degrees of reliance } \\
\text { on subsistence and small-scale } \\
\text { agricultural and fisheries } \\
\text { livelihoods; few livelihood } \\
\text { alternatives. Declining quality of } \\
\text { marine and land resources. Long } \\
\text { history of comanagement. }\end{array}$ & $\begin{array}{l}\text { National and provincial } \\
\text { governments support } \\
\text { community-led natural resource } \\
\text { management in policy, but } \\
\text { capacity restricts their support in } \\
\text { practice. Mechanisms exist for } \\
\text { local representation in national } \\
\text { policy fora but are functioning } \\
\text { suboptimally. Locally, tenure } \\
\text { rights and gender norms } \\
\text { influence representation. }\end{array}$ & $\begin{array}{l}\text { Legal plurality, with state and } \\
\text { traditional governance of } \\
\text { natural resources. Constitutional } \\
\text { recognition of customary } \\
\text { institutions. At local level } \\
\text { authority to govern is } \\
\text { determined by clan/socially } \\
\text { defined customary tenure rights, } \\
\text { while use rights are more } \\
\text { distributed. }\end{array}$ & $\begin{array}{l}\text { Fisheries and agricultural policies } \\
\text { promote recognition of local and } \\
\text { customary governance. Political } \\
\text { commitments emphasize upward } \\
\text { accountability. Multistakeholder } \\
\text { networks aim to promote } \\
\text { informal vertical and horizontal } \\
\text { accountability mechanisms. }\end{array}$ \\
\hline $\begin{array}{l}\text { Barotse } \\
\text { Floodpl- } \\
\text { ain, } \\
\text { Zambia }\end{array}$ & $\begin{array}{l}\text { Zambezi River floodplain. } \\
\text { Territory of the Lozi kingdom, } \\
\text { traditionally governed by the } \\
\text { Barotse Royal Establishment } \\
\text { (BRE). Local livelihoods linked to } \\
\text { the flood pulse and seasonal } \\
\text { movement on and off the plain. } \\
\text { Poorest province in Zambia. } \\
\text { Supply of fish is important for } \\
\text { trade at national level, also for } \\
\text { export to DRC. Decline in fishery } \\
\text { in recent decades. }\end{array}$ & $\begin{array}{l}\text { Water, land, and fisheries } \\
\text { resources managed through a } \\
\text { dual governance system } \\
\text { involving traditional authorities } \\
\text { and state agencies. Tension and } \\
\text { lack of trust between the two } \\
\text { contributing to decline in natural } \\
\text { resources. }\end{array}$ & $\begin{array}{l}\text { Legal plurality, with state tenure } \\
\text { over the main river channel while } \\
\text { the myriad lagoons, lakes, and } \\
\text { smaller waterways are under } \\
\text { customary tenure. Landholders } \\
\text { and their representatives and } \\
\text { local leaders control access to the } \\
\text { fishery. Unlike other parts of the } \\
\text { country, government does not } \\
\text { issue fishing licenses. Authority } \\
\text { and legitimacy continue to be } \\
\text { largely contested. }\end{array}$ & $\begin{array}{l}\text { The Fisheries Act of } 2011 \text { allows } \\
\text { for comanagement. However, } \\
\text { accountability is largely upward to } \\
\text { the state with local and vertical } \\
\text { accountability being partially } \\
\text { undermined by the state, hesitant } \\
\text { to increase local autonomy. }\end{array}$ \\
\hline $\begin{array}{l}\text { Southern } \\
\text { Polder } \\
\text { Zone, } \\
\text { Bangla- } \\
\text { desh }\end{array}$ & $\begin{array}{l}\text { Coastal delta system with varying } \\
\text { salinity gradients. High } \\
\text { population density with disparity } \\
\text { between landowners and landless, } \\
\text { and ethnic minorities having less } \\
\text { access to natural resources. } \\
\text { Agriculture and aquaculture } \\
\text { dependent livelihoods are affected } \\
\text { by extreme climatic events and } \\
\text { increasing salinity. }\end{array}$ & $\begin{array}{l}\text { Poor implementation of local } \\
\text { water management organizations } \\
\text { (WMOs) restricts formation of } \\
\text { legitimate groups representing } \\
\text { landless, smallholder farmers, } \\
\text { and women. Strong but informal } \\
\text { influence of local government } \\
\text { and elites in decision making. } \\
\text { Decisions typically driven by } \\
\text { government demand as opposed } \\
\text { to stakeholder-led coordination. }\end{array}$ & $\begin{array}{l}\text { Formally the law distributes } \\
\text { authority at different levels from } \\
\text { Ministries to WMOs but lack of } \\
\text { clarity in the distribution of } \\
\text { authority creates gaps as well as } \\
\text { overlaps in practice. Local level } \\
\text { dispute resolution mechanisms } \\
\text { are rarely effective and legal } \\
\text { cases are often used to } \\
\text { redistribute authority. Role of } \\
\text { local government institutions in } \\
\text { water management is largely } \\
\text { informal. }\end{array}$ & $\begin{array}{l}\text { Shift from public to private } \\
\text { decision making over resources } \\
\text { reduces the accountability of } \\
\text { resource users toward public } \\
\text { institutions. Without elections to } \\
\text { appoint leaders, WMOs have few } \\
\text { incentives to keep decision makers } \\
\text { accountable. By contrast, social } \\
\text { justice NGOs and social } \\
\text { movements are more effective in } \\
\text { promoting accountability in water } \\
\text { governance. }\end{array}$ \\
\hline $\begin{array}{l}\text { Tonle } \\
\text { Sap } \\
\text { Lake, } \\
\text { Cambodia }\end{array}$ & $\begin{array}{l}\text { Highly productive lake and } \\
\text { floodplain, driven by the flood } \\
\text { pulse of the Mekong River, } \\
\text { supporting approximately } 1.5 \\
\text { million people, Rice is grown by } \\
\text { over } 70 \% \text { of the rural population, } \\
\text { and diverse capture fisheries } \\
\text { contribute } 80 \% \text { of animal protein. } \\
\text { Destructive fishing, land use } \\
\text { change, weak value chains, and } \\
\text { low human capital combine to } \\
\text { maintain high levels of poverty, } \\
\text { particularly for those dependent } \\
\text { on fishing. }\end{array}$ & $\begin{array}{l}\text { Opportunities for community- } \\
\text { driven resource governance } \\
\text { offered by decentralized } \\
\text { planning systems are difficult for } \\
\text { poor farmers and fishers to } \\
\text { access in practice. Without a } \\
\text { dedicated means of finance, } \\
\text { community fisheries struggle to } \\
\text { realize their potential. } \\
\text { Significant problems of elite } \\
\text { capture. }\end{array}$ & $\begin{array}{l}\text { Highly pluralistic institutional } \\
\text { landscape generating multiple } \\
\text { points of authority translated } \\
\text { into legal and illegal control over } \\
\text { access to resources. Rampant } \\
\text { rent seeking penalizes the poor } \\
\text { and undermines rule } \\
\text { enforcement overall. Tonle Sap } \\
\text { Authority struggles to exercise its } \\
\text { overarching management } \\
\text { mandate, with low human } \\
\text { capital, and roles of line agencies } \\
\text { under review. }\end{array}$ & $\begin{array}{l}\text { Accountability of commune } \\
\text { councils as the primary conduit } \\
\text { for decentralized rural } \\
\text { development highly variable, } \\
\text { depending heavily on individual } \\
\text { personalities (e.g., commune } \\
\text { chief). Intense politicization of } \\
\text { commune councils and their } \\
\text { election process undermines } \\
\text { downward accountability. Village } \\
\text { heads are selected by Commune } \\
\text { Chief and not elected. }\end{array}$ \\
\hline
\end{tabular}

to increase their agriculture and aquaculture productivity as a means to improve nutrition of poor and marginalized families. Water management was identified as an overarching constraint to productivity, with problems including management of water infrastructure (such as broken sluice gates and silted canals), and adapting to natural phenomena (such as tidal surges or salinity intrusion). At this early stage of implementation, participants were unwilling to explicitly discuss the institutional dimensions of water management systems and governance, such as the water management organizations (WMOs), that were known to not be performing effectively (Kenia and Buisson 2015). A window of opportunity, therefore, was visible, but most participants considered changes to these institutions to be beyond their control. Elites predominately controlled natural and financial resources and the less powerful were unwilling to challenge their authority. 
Table 2. Windows of opportunity and emerging changes in each of the cases.

\begin{tabular}{|c|c|c|c|}
\hline $\begin{array}{l}\text { Case } \\
\text { Study } \\
\end{array}$ & $\begin{array}{l}\text { Development } \\
\text { challenge }\end{array}$ & First tier (technical) opportunity & Second tier (governance) opportunity \\
\hline $\begin{array}{l}\text { Malaita } \\
\text { and } \\
\text { Western } \\
\text { Province, } \\
\text { Solomon } \\
\text { Islands }\end{array}$ & $\begin{array}{l}\text { High levels of } \\
\text { reliance on } \\
\text { natural } \\
\text { resources for } \\
\text { food and } \\
\text { income leading } \\
\text { to resource } \\
\text { decline and } \\
\text { failing to } \\
\text { support } \\
\text { human well- } \\
\text { being. }\end{array}$ & $\begin{array}{l}\text { Opportunity: Recognition that local levels required support } \\
\text { to implement management solutions and new livelihood } \\
\text { opportunities. Willingness of local leaders to engage } \\
\text { broader community in resource management and livelihood } \\
\text { efforts. } \\
\text { Action: Technical intervention focused on establishment of } \\
\text { improved resource management (fisheries management and } \\
\text { new farming practices) in rural communities. } \\
\text { Change: New governance processes and structures } \\
\text { introduced by researcher-facilitators to develop community- } \\
\text { based, comanagement arrangements to improve equity in } \\
\text { local decision making. Localized improvements to specific } \\
\text { aspects of fisheries and agriculture. }\end{array}$ & $\begin{array}{l}\text { Opportunity: Formal (legal and policy) legitimacy and } \\
\text { recognition of the authority of local community governors } \\
\text { in addressing coastal resource concerns. Existence of } \\
\text { multistakeholder and cross-sector networks to tackle } \\
\text { resource management and development concerns (but with } \\
\text { low capacity to coordinate and address accountability). } \\
\text { Action: Investment in building and supporting existing } \\
\text { multistakeholder networks, linked to raising awareness of } \\
\text { PAR at local levels. } \\
\text { Emerging change: Some improvements (and persistent } \\
\text { challenges) in the function of mechanisms to support more } \\
\text { equal representation and accountability across scales of } \\
\text { marine resource governance and development practice. }\end{array}$ \\
\hline $\begin{array}{l}\text { Barotse } \\
\text { Floodplain, } \\
\text { Zambia }\end{array}$ & $\begin{array}{l}\text { Reduced } \\
\text { incomes and } \\
\text { nutrition from } \\
\text { decline in fish } \\
\text { catches and } \\
\text { lack of access } \\
\text { to markets } \\
\text { related to poor } \\
\text { management } \\
\text { of the fishery. }\end{array}$ & $\begin{array}{l}\text { Opportunity: Commitment to work collaboratively to } \\
\text { better understand the fish value chain to improve access to } \\
\text { markets and reduce postharvest fish loss. } \\
\text { Action: Multistakeholder engagement through a fish value } \\
\text { chain innovation platform, with interventions designed } \\
\text { based on a value chain assessment and theory of change } \\
\text { planning exercise. } \\
\text { Change: New relationships among fish value chain actors } \\
\text { leading to ongoing collaborations such as testing of new } \\
\text { fish preservation technologies through PAR with traders } \\
\text { and fishers. }\end{array}$ & $\begin{array}{l}\text { Opportunity: Collective commitment to improve } \\
\text { comanagement arrangements and tackle the conflict } \\
\text { between Barotse Royal Establishment and the state. } \\
\text { Action: Multistakeholder working group established, } \\
\text { including fish value chain actors. } \\
\text { Emerging change: Greater representation in fishery } \\
\text { comanagement with stronger links between responsible } \\
\text { local, provincial, and government entities. }\end{array}$ \\
\hline $\begin{array}{l}\text { Southern } \\
\text { Polder } \\
\text { Zone, } \\
\text { Bangladesh }\end{array}$ & $\begin{array}{l}\text { Poor nutrition } \\
\text { and low } \\
\text { incomes from } \\
\text { low } \\
\text { agricultural } \\
\text { and } \\
\text { aquaculture } \\
\text { productivity in } \\
\text { part related to } \\
\text { water } \\
\text { management } \\
\text { challenges. }\end{array}$ & $\begin{array}{l}\text { Opportunity: Joint recognition of need to improve } \\
\text { productivity through farming and aquaculture in the } \\
\text { context of rapid ecological change. } \\
\text { Action: Productivity improvement initiative including PAR } \\
\text { field experiments with men and women farmers to improve } \\
\text { vegetable seeds, livestock fodder, and homestead fish ponds. } \\
\text { Change: Improvements in homestead productivity and } \\
\text { community recognition of farmer researchers, particularly } \\
\text { women who had previously been marginalized. }\end{array}$ & $\begin{array}{l}\text { Opportunity: Collective commitment to improve } \\
\text { representation in existing water management organizations } \\
\text { where women, landless and smallholder farmers were } \\
\text { previously excluded. } \\
\text { Action: Experimental games on common interest and } \\
\text { management of public goods to aid formation of gender- } \\
\text { balanced land and water groups based on hydrological units, } \\
\text { inclusive of all households cultivating land (landowners, } \\
\text { sharecroppers, leasers, informal tenants). } \\
\text { Emerging change: Better awareness in local government and } \\
\text { in some government departments of necessity to strengthen } \\
\text { representation of more diverse stakeholders in water } \\
\text { management decision making. }\end{array}$ \\
\hline $\begin{array}{l}\text { Tonle Sap } \\
\text { Lake, } \\
\text { Cambodia }\end{array}$ & $\begin{array}{l}\text { Poor nutrition } \\
\text { and health } \\
\text { related to poor } \\
\text { management } \\
\text { of natural } \\
\text { resources on } \\
\text { the floodplain. }\end{array}$ & $\begin{array}{l}\text { Opportunity: Joint recognition of need to improve quality } \\
\text { of drinking water in floating communities, as well as water } \\
\text { management in linked fish and rice production systems in } \\
\text { lakeshore communities. } \\
\text { Action: NGOs and government partnered to address } \\
\text { community concerns, bringing technical expertise and } \\
\text { facilitating community engagement processes. } \\
\text { Change: Improved management of water filter stations and } \\
\text { improved rice field fisheries initiatives. }\end{array}$ & $\begin{array}{l}\text { Opportunity: Recognition that gaps in representation and } \\
\text { accountability of local management committees create } \\
\text { inequities. } \\
\text { Action: Efforts to institute locally representative, } \\
\text { multistakeholder management committees. } \\
\text { Emerging change: New institutional structures } \\
\text { implemented, but collusion of local elites hinders equitable } \\
\text { representation. Through broader engagement some } \\
\text { individuals in government departments are becoming more } \\
\text { aware of the underlying institutional challenges. }\end{array}$ \\
\hline
\end{tabular}

In the same communities, associated farmer-led participatory action research began to address agricultural and technical concerns through field experiments to select better quality vegetable seeds, livestock fodder species, and improved management of homestead fish ponds. Men and women worked with members of the research-facilitation team from NGOs and local universities, learning how to experiment, analyze results, reflect on the implications, and share their findings with the community. During reflection and learning events, an increase in confidence and leadership of participating farmers was reported as an outcome of this initial technical engagement. The emerging changes were subsequently investigated through evaluation research, which substantiated observations by facilitators of women farmers gaining confidence and having more voice. For example, it found that women in some communities now had "greater freedom to join learning events" (R. Paz-Ybarnegaray, K. Kamp, and T. Clayton, 2014, unpublished manuscript). One of the points that women clearly articulated during the collective analysis of field results, was that a lack of access to quality productive land was compromising their field experiments.

The discussion about equity in access to land, in turn, prompted more explicit discussion about exclusion faced by women, landless, and smallholder farmers from decision making more 
generally. The exclusion was most evident in the WMOs that lacked representation of women, the poorest families, and the landless (Dewan et al. 2014, Naz and Buisson 2015). A new stream of research was consequently implemented, building on the confidence gained by under-represented stakeholders to address their concerns about representation. Diverse stakeholder groups in the community were brought together to form new water and land groups to test models based on hydrological units for land and water management and cultivation. At this early stage, it is not yet possible to determine to what degree power has been redistributed as a result and whether that will in turn lead to improved accountability in water governance. What has emerged, is an improved ability of previously under-represented stakeholders to engage in broader decision-making processes.

In the Barotse floodplain in Zambia, stakeholders were primarily concerned with declining fisheries resources, low catches, and reduced profitability. During the initial multistakeholder engagement process, conflict between traditional and state authorities, among other institutional constraints, was identified as contributing toward fishery decline, and inhibiting progress toward adaptive comanagement (Madzudzo et al. 2013; AAS CRP Barotse Floodplain stakeholder consultation workshop, unpublished report). This conflict is best illustrated by the government's introduction, in 1998, of an annual three-month national fish ban, which was effectively blocked by the Barotse Royal Establishment (BRE) until local concern about declining catches compelled the BRE to agree to the ban in 2002. The ban continues to be poorly executed because of low enforcement capacity, corruption among enforcement agencies, and dependence of local authorities on income from issuing fishing permits. As a result, fishing during the ban and use of illegal gears continues to contribute to decline of the fishery.

In spite of institutional conflict having been identified early on, there was not yet a window of opportunity for change. A combination of inability to openly challenge leadership due to traditional norms, and fear of fueling further conflict, meant that stakeholders were not able to tackle the governance challenges of the fishery head on. Together, system level stakeholders and the research-facilitation team agreed to focus an immediate and joint intervention on the concern of villagers around income generation from the sale of fish; the first stage to this was to build a better and more collaborative understanding of the performance of the fish value chain. Stakeholders agreed to apply PAR principles to a fish value chain assessment (Longley et al. 2016). The collaboration involved three rounds of data collection and feedback, each followed by a series of reflections on methods by researcher-facilitators and then a workshop for data analysis and interpretation including system-level stakeholders. Learning from each round was then used to improve the PAR design and implementation. The co-ownership of the research process meant that the workshops were able to build an increasingly "safe space" to discuss sensitive issues.

During implementation, poor comanagement of the fishery continued to surface as an underlying driver of fishery decline. Nonetheless, it took over six months of facilitated collaborative research and engagement for the institutional challenges to be discussed openly. The final stakeholder workshop brought together fishers, processors, and traders from the data collection sites as well as system-level stakeholders. Discussions moved on from the value chain and participants talked openly about corruption among village headmen and Department of Fisheries (DoF) officers, the gap between the BRE and DoF, and the need for consistency and coordination between these two organizations, as well as the lack of representation of fishers in various decision-making processes. It was in this particular forum, after a period of technical engagement, that the second tier window of opportunity opened and could be pursued. Stakeholders and the researcher-facilitators consequently together designed a working group tasked specifically with establishing adaptive comanagement of fisheries, and particularly fostering links between institutions and scales.

Using reflexive engagement to support more equitable governance An explicit intent in all the cases (embodied in the PAR principle of "equity") was to understand, and even attempt to transform existing power dynamics where they marginalized certain groups from decision making and delivered inequitable outcomes (Kantor and Apgar 2013). The principle was addressed in part through facilitated sessions designed to support "critical reflection" (e.g., Chiu 2006). Further, CRP AAS invested in building the capacity of the research-facilitation team, and in particular equipped them with participatory tools, e.g., safe/ unsafe spaces and power cube, to open up discussion about power dynamics within activities (see Nurick and Apgar 2014 for examples). Subsequent to these capacity building efforts, the research-facilitation teams developed their own engagement strategies. In all cases, certain groups initially remained invisible in public PAR activities. It required a good knowledge of power dynamics to identify and then act upon opportunities for including the marginalized. Nonetheless, we found that affecting change at deeper institutional levels relied heavily on attributes of the powerful themselves, including formal leaders, and at times facilitators were unable to achieve equal representation and voice in meetings and activities.

In Solomon Islands, system-level stakeholders and rural communities expressed concern that in the context of high reliance on small-scale and subsistence agriculture and fisheries they were facing "challenges from rising population and declining quality and availability of marine and land resources" (Govan et al. 2013:4). As a result, they wanted to pursue improvements to peoples' lives through "more productive, diversified livelihoods that empower communities to be better able to adapt to change and make more effective use of their resources" (Govan et al. 2013:4). These goals aligned to expertise within the researchfacilitation teams, and the first window of opportunity was to facilitate localized improvements to management and development opportunities associated with natural resources. In contrast to Zambia, Solomon Islands had a long history of success in community-based comanagement (Cohen et al. 2012). Most of these efforts had been implemented in Western Province, so efforts concentrated firstly in Malaita Province where very few such initiatives had been implemented. Simultaneously, there was enthusiasm expressed for improving coordination amongst multiple stakeholders to develop cross-sector solutions that would be more effective and accountable to local community needs.

Contemporary community-based comanagement initiatives aim to build stewardship and opportunities upon existing local 
governance arrangements, including those associated with customary tenure. CRP AAS commenced some localized efforts to promote community-based management and, within these, attempted to navigate the balance between respecting local governance arrangements, and promoting more inclusive processes aligned with locally defined ideals of good governance (Albert et al. 2013, Cohen and Steenbergen 2015). In practice, researcher-facilitators employed community-wide consultations, separate consultations with men and women, and the formation of resource management or community development committees. These strategies required an investment in the team's capacity, i. e., building skills from technical fisheries management advisors to community development facilitators. Despite these efforts, we found that without some level of external facilitation, the structures (committees) and processes (community-wide consultation) tended to erode. Although there were tangible achievements in developing technical fixes, i.e., fisheries management plans were established and implemented, shifts in the deeper governance contexts such as representation in decision making and the distribution of authority were more complex, slower, and remain a focus of ongoing research.

In the Tonle Sap Lake of Cambodia, resource decision making tends to be concentrated among elites; for example, communal areas are increasingly appropriated by those with connections to private investors, leaving small scale farmers and fishers who had customary user rights without access to quality land and water bodies (Keskinen et al. 2007, Diepart 2010). The first opportunity to engage collectively came through addressing technical concerns related to water management and fisheries. In Phat Sanday commune a response to the locally identified need to improve the quality of drinking water was designed by a national partner of CRP AAS mandated with resource management responsibilities in the Tonle Sap. The response was designed following technical analysis of the filter stations. Concurrently, the researchfacilitation team built understanding of the governance aspects around drinking water through focus group discussions and interviewing key informants (de Silva 2014). Analysis revealed that there was little representation of poorer households in the station management committees, and no accountability mechanisms with respect to water pricing or quality, the two most important aspects for households. Yet the methods used were unable to reveal details on functioning of the committees and the power relations that were obstacles to increasing representation and accountability.

As technological improvements to the water station were pursued, along with other technical initiatives linked to fisheries management, in Phat Sanday commune, the research-facilitation team built closer relationships with stakeholders who demonstrated openness to pursuing a more accountable governance mechanism. This enabled informal conversations and discrete dialogues outside of collective meetings (de Silva 2014) that created a safe space where more details could be shared. The conversations revealed that the water stations had been appropriated by council members and were being run for personal profit. Villagers had been unwilling to speak out publicly against the elites in the public consultations, and they later explained this was because they felt dependent on the elites who had control over the best fishing grounds and offered protection against prosecution for illegal fishing, which fishers found at times was necessary to sustain their livelihoods in the face of declining fish stocks.

Recognizing that addressing the root of these problems would require changes by both marginalized community members and elites, the research-facilitation team organized discussions around more equitable governance to nurture a collective voice for change. Investments in technical upgrades to two water stations were used as leverage with elites to stimulate the creation of a new, and hopefully more representative, management committee. Ten months after the establishment of the new committee, a meeting of system level stakeholders and village representatives was facilitated to undertake a critical reflection of progress. In this meeting it was revealed that the new committee had been merely a false semblance of reform, given that several committee members professed they were not even aware of their membership, or if aware, had not been invited to any committee meetings. They summarized that control over water station operations remained firmly in the hands of the elites. Further, the reflection showed that inequitable local resource governance is intimately linked to poor governance practices at higher administrative levels, because strong lines of upward accountability reinforced inequities at the community level.

\section{Facilitating links across scales to address local priorities}

Our analysis of the governance context in AAS sites illustrates inadequacies in linkages across scales. Cross-scale governance challenges were identified by stakeholders at the outset of intervention to be more pressing, or more readily amenable to action, in Solomon Islands and Zambia (Table 1). By contrast, in Cambodia the importance of cross-scale interactions on elements of governance was revealed at later stages in response to successes and challenges faced in the technical intervention. In Solomon Islands and Zambia, therefore, specific efforts were made to broker links with the intention of fostering improvements in representation, accountability, and distribution of authority across scales. Efforts focused largely on the need for greater representation of local interests in higher-level institutions, and increased accountability of power-holders at broader (provincial or national) scales to the poor and marginalized.

A lack of productive institutional linkages, and even conflicts, between traditional and government bodies across scales had been identified in the Barotse Floodplain in Zambia as contributing to fishery decline. Researcher-facilitators, therefore, explicitly worked toward fostering linkages between fisheries managers across scales from community to provincial and national levels, and between traditional, i.e., BRE, and government institutions, i.e., DoF. Researchers focused efforts first on bringing the BRE and DoF together to work on tangible tasks on the ground, rather than directly addressing the highly political national level relationships. These tasks revolved mainly around linking in to local level management processes by jointly facilitating consultative meetings in communities early in implementation to create awareness about the Fisheries Act of 2011, which promotes fisheries comanagement, and gather ideas on how local-level fisheries comanagement committees might be formed. In one of these meetings, a community member remarked, "We are glad that this idea [of fisheries comanagement] is coming back. In 1996, the community here resolved that we should work together with DoF and BRE in managing our fish. With time, it is true that 
things did not go as planned due to difficulties working with DoF and BRE, but it can be done."

One of the factors that contributed to successful collaboration between the two institutions was a broader collaboration with civil society organizations (CSOs) including the Zambezi Fish Conservation Association (ZFCA) and two local fish trader associations. ZFCA played a brokering role in facilitating interactions between DoF and BRE and together with the CSOs they developed an action plan to sensitize communities about the fishing ban of December 2014-February 2015. Local level leaders appeared receptive to the message about the fishing ban because it was delivered jointly by DoF, BRE, and CSOs. The outcomes of this effort were distinct from earlier efforts by these actors when DoF and BRE had been working independently, and resulted in the establishment of a number of comanagement committees at community level and a ban on the sale of small fish instituted by the BRE. At a meeting in December 2015, the DoF's Provincial Officer reflected on the importance of the brokering role researchers played that resulted in an unprecedented level of collaboration between DoF and BRE. It remains to be seen whether this level of collaboration will continue in the absence of active and dedicated brokering by researcher-facilitators.

In Solomon Islands cross-scale governance had been a focus of actors and initiatives predating CRP AAS. The program aimed to utilize and strengthen these existing networks. For example, this included working in an advisory capacity to the Solomon Islands locally managed marine area network, one of the most enduring institutions for promoting learning and coordination between NGOs, government, and community partners implementing community based resource management (Cohen et al. 2013). Newer governance networks included the National Coordinating Committee of the Coral Triangle Initiative, and the Malaita Provincial Partnership for Development (MPPD). These three networks all had objectives to increase local level representation in national or provincial decision making, to improve accountability between government and NGOs, development and natural resource management partners, and to promote coordination and learning among multiple system level stakeholders.

Some notable improvements in upward and horizontal accountability and coordination emerged during this study. For example, the Malaita Provincial government expressed an intent to formally recognize the MPPD, community-based approaches were recognized as principle strategies in national policies, and fisheries and environment legislation was amended to legally back community management efforts. This political landscape was different, and more attuned to NGO and community-level representation and downward accountability, than observed in other cases. Although CRP AAS invested in these areas (Table 2), these achievements were in fact long in the making, slow to take shape, and hard to attribute to a discrete set of actors and actions.

\section{DISCUSSION}

The four AAS case studies have demonstrated that in certain contexts, PAR can be used effectively not only to assess governance constraints in a participatory manner, but also to engage diverse stakeholders in reflective dialogue over opportunities to improve governance arrangements. As Ratner et al. $(2013 a)$ note, there are multiple entry points to contribute to governance improvement, which may begin, for example, with the analysis and reform of state policies, or capacity building support to natural resource management institutions. Our analysis has focused on the domain of the action arena, in which multiple, often competing, stakeholders interact to address disputes and pursue their aims. Working within these arenas, we've used the dimensions of governance context proposed by Ratner et al. (2013b) not only to characterize the constraints but also to explore and pursue opportunities for change. By analyzing the iterative process of assessment, action, reflection, and adaptation in the case studies, we have aimed to illustrate the dynamic nature of the windows of opportunity commonly cited in the literature on social-ecological resilience and transformation (e.g., Olsson et al. 2006) and shed light on the role that researcher-facilitators can play in the change process.

Our results show that the action arenas within which governance change can be pursued, are not singular or discrete in time. We suggest that to reach opportunities for governance change it may be necessary to navigate through successive windows of opportunity. Though collectively arriving at a common vision is an obvious starting point for collaborative initiatives, the sensitivity in naming obstacles related to power and institutions (as demonstrated in each case) means that it may be necessary to first build momentum, trust, collaborative links and patterns of communication in more technical areas, such as through improved management of agricultural, fisheries, or water resources (as shown in Table 2). We found that the use of ongoing PAR engagement to address these readily-acknowledged technical constraints can in fact build confidence in collaborative efforts and invite opportunities to address more difficult governance constraints. Second-tier windows of opportunity for governance change emerged once there was momentum with stakeholders using PAR that enabled more critical assessment of underlying institutional constraints and actions to address these. Governance constraints, therefore, were identified not in spite of but because of their explicit connection to other more immediate and tangible concerns such as productivity, income generation, health, and nutrition benefits.

For engaged researchers, working to identify, open, and pursue such opportunities for change brings a heightened level of responsibility. Collaborative governance theorists refer to this as the challenge of fostering "principled engagement," characterized by the identification of shared interests and values, articulation of common purpose and goals, robust deliberation over alternate courses of action, and joint decisions (Emerson et al. 2012). "The effectiveness of principled engagement is determined, in part, by the quality of these interactive processes," which can contribute to trust, mutual understanding, legitimacy, and shared commitment necessary to motivate further change efforts (Emerson et al. 2012:13-14). Achieving such principled engagement to support collaborative governance is known to be a challenge that requires building institutional and researcher commitment to the approach, as well as ensuring the right skills for quality in practice (e.g., Colfer et al. 2011, Ojha et al. 2013).

Principles of equity, coinquiry, and critical reflection were applied by researcher-facilitators of the PAR processes in CRP AAS. Some propose that such principled PAR can foster safe spaces 
(Rom 1998, Wicks and Reason 2009) to address issues of representation, power, and accountability that might otherwise be considered too risky to consider as a focus of joint action. The cases illustrate multiple pathways to achieving this: by building on the legitimacy created through longstanding partnerships and prior resource management and livelihood development outcomes achieved (Solomons), by working with previously competing authorities to jointly sponsor new participatory analysis of shared resource management and development challenges (Zambia), by building trust through individual relationships within the community and pursuing informal discussions to better understand hidden power relationships (Cambodia), and even by organizing collective action games that allow stakeholders to test different scenarios and the implications for resource sustainability and equity (Bangladesh). Critical in all the AAS cases was the capacity of research-facilitation teams to foster appropriate and effective safe spaces within each context, and their commitment to accompanying the journey toward governance change.

Although leadership is recognized as a key driver of governance transformation (Scheffer et al. 2003, Olsson et al. 2008, Biggs et al. 2010, Westley et al. 2011), the leadership role that researchers play is often missed (Westley et al. 2013). Further, much literature citing the importance of leadership in mainstream environmental sciences has failed to present a critical analysis of how leaders are empowered, how they enact their power, and where leaders block or stall more equitable outcomes (Evans et al. 2015, Case et al. 2015). In the case of the CRP AAS research-facilitation teams, their intent was to ensure that program aspirations were aligned with local, provincial, and national level aspirations and to empower local stakeholders to decide and drive their own development priorities. In implementing the program, we as researcher-facilitators were active participants, and sometimes leaders, in change processes (Burns 2007). This meant at times choosing between reinforcing existing institutions and challenging them, recognizing that existing governance structures, including both state and traditional institutions, may not necessarily promote accountability, representation, or distributed decision-making authority (Ribot 1999, Béné et al. 2009). This was particularly challenging in Cambodia where the allegiances among state authorities at multiple levels risked undermining the social equity goals of the program. In contested governance settings (e.g., Molle et al. 2010), researchers must rely on their skills to navigate inherent tensions so that their equity goals are supported by a critical, analytical perspective into the learning processes they are facilitating (e.g., Reason 2006, Roberts and Dick 2003).

Vital to navigating these dynamics is researcher understanding of power dynamics in context. Without sufficient understanding of the complexities of the multiple dimensions of power differentiated by social groups (gender, wealth, physical location, livelihood/economic groups, etc.), interventions that aim to improve livelihoods may in fact reinforce existing inequalities. In Bangladesh and in the Solomons, for example, women and nonlandowners are more likely to be marginalized from decisions about how natural resources are used, developed, and managed (Foale and Macintyre 2000, Crow and Sultana 2002, Cohen et al. 2016). Customary tenure systems often give certain individuals and groups preferential access and more power in decision making than others. Simplistic applications of tools to promote greater participation and more inclusive consultation will, in some cases, be insufficient to sustainably address such underlying governance challenges.

The resilience literature suggests that solutions required to address multiple development objectives in complex systems like AAS require multiscale or polycentric governance arrangements (Lebel et al. 2006, Biggs et al. 2010, 2015). More specifically, relations that promote learning, negotiation, and representation across scales are thought to be necessary for solutions to be fit for the complexity of problems faced in social-ecological systems (Cash et al. 2006). In the two cases where engagement across scales was explicitly pursued, we found that the relationships and links between agencies, across jurisdictions, and between institutions were first built to identify and address technical challenges (productivity of the fishery in Zambia, for example). Similar to what we observed at the local scale, once these relations were established to address a technical challenge they could then be leveraged and adapted to address governance challenges (navigating conflict between governance institutions, for example). In the Solomon Islands case, this led to the deliberate formation of what could be described as a governance network (sensu Newig et al. 2010), or a field-policy or organizational leadership network (sensu Hoppe and Reinelt 2010) to align resources and influence policies across scales to address common goals.

Building and sustaining new relationships and mechanisms for governance requires substantial investment of time and resources at local or higher levels, and brings its own risks. As the cases illustrate, fostering governance change is strongly influenced by a broader political environment that may enable or hinder improvements in representation, accountability, and distribution of authority (Adger et al. 2005, Mwangi and Wardell 2012). In Solomon Islands, for example, even after multiple system level stakeholders had invested years of effort, significant capacity, and finances into the SILMMA network, it continued to face substantial challenges to sustain and realize the functions of improved representation and coordination across scales (Cohen et al. 2013, Ratner et al. 2013b). Examples from the local level highlight that the success and sustainability of new governance relationships or mechanisms is heavily influenced by the personal attributes of clan and community leaders (Abernethy et al. 2014), their tendencies to buy-in to equitable processes, and their sustained alignment to the originally articulated objectives around resource management. Support to change in higher level institutions can have a substantially broader reach, yet there may be cases where the diversion of resources and time toward brokering linkages across scales comes at the expense of local progress. This further illustrates the tensions that researcherfacilitators must navigate in pursuing principled engagement, using their knowledge of power across scales, plus their skills in facilitating critical reflection among stakeholders to weigh alternate courses of action and to learn and adapt on the basis of early results.

\section{CONCLUSION}

Challenges of governance often constitute critical obstacles to efforts that seek to equitably improve livelihoods reliant on natural resources. Beginning with technical resource management 
challenges as a starting point, CRPAAS applied an equity focused governance assessment together with PAR principles to identify underlying governance challenges and to create the space for constructive dialogue and collective action to facilitate governance improvements. Such an approach offers stakeholders an opportunity to reflect on and pursue changes in representation, distribution of authority and accountability at local scales, and in cross-scale governance interactions. Yet it also requires a significant shift in the typical understanding of the role that researchers can play, challenging the traditional view of researchers as external observers and encouraging them to become more embedded in order to navigate with stakeholders the processes of transformation in social-ecological systems. This demands sensitivity to issues of social differentiation, historical and contemporary power dynamics, and a high degree of adaptability to identify and respond to the opportunities for change.

Responses to this article can be read online at: http://www.ecologyandsociety.org/issues/responses. $\mathrm{php} / 8929$

\section{Acknowledgments:}

We wish to acknowledge the skills and dedication of the many community facilitators and partner organizations that have made this work possible in all countries over the course of implementation of the CGIAR Research Program on Aquatic Agricultural Systems.

\section{LITERATURE CITED}

Abernethy, K., Ö. Bodin, P. Olsson, Z. Hilly, and A. Schwarz. 2014. Two steps forward, two steps back: the role of innovation in transforming towards community-based marine resource management in Solomon Islands. Global Environmental Change 28:309-321. http://dx.doi.org/10.1016/j.gloenvcha.2014.07.008

Adger, W. N., K. Brown, and E. L. Tompkins. 2005. The political economy of cross-scale networks in resource co-management. Ecology and Society 10(2):9. http://dx.doi.org/10.5751/es-01465-100209

Albert, J., A.-M. Schwarz, P. Cohen, D. Boso, J. Oeta, Z. Hilly, R. Posala, S. Sibiti, J. Pita, T. Alexander, R. Maetala, A. VaveKaramui, F. Siota, D. Harohau, G. Orirana, H. Govan, and R. Masu. 2013. Community-based marine resource management in Solomon Islands: a facilitators guide. CGIAR Research Program on Aquatic Agricultural Systems. WorldFish Center, Penang, Malaysia. [online] URL: http://pubs.iclarm.net/resource centre/ AAS-2013-17.pdf

Apgar, M., and B. Douthwaite. 2013. Participatory action research in the CGIAR research program on aquatic agricultural systems. CGIAR Research Program on Aquatic Agricultural Systems. WorldFish Center, Penang, Malaysia. [online] URL: http://www.worldfishcenter.org/content/participatory-action-researchcgiar-research-program-aquatic-agricultural-systems

Aquatic Agricultural Systems (AAS). 2011. CGIAR research program on aquatic agricultural systems: program proposal. CGIAR Research Program Aquatic Agricultural Systems.
WorldFish Center, Penang, Malaysia. [online] URL: http://www. worldfishcenter.org/content/program-proposal-0

Aquatic Agricultural Systems (AAS). 2013. Learning from implementation of community selection in Zambia, Solomon Islands, and Bangladesh AAS hubs. CGIAR Research Program on Aquatic Agricultural Systems. Penang, Malaysia. Evaluation and Learning Series Paper: AAS-2013-24

Armitage, D. R., R. Plummer, F. Berkes, R. I. Arthur, A. T. Charles, I. J. Davidson-Hunt, A. P. Diduck, N. C. Doubleday, D. S. Johnson, M. Marschke, P. McConney, E. W. Pinkerton, and E. K. Wollenberg. 2009. Adaptive co-management for socialecological complexity. Frontiers in Ecology and the Environment 7(2):95-102. http://dx.doi.org/10.1890/070089

Barrett, C. B., A. J. Travis, and P. Dasgupta. 2011. On biodiversity conservation and poverty traps. Proceedings of the National Academy of Sciences of the United States of America 108 (34):13907-13912. http://dx.doi.org/10.1073/pnas.1011521108

Bavinck, M., R. Chuenpagdee, S. Jentoft, and J. Kooiman, editors. 2013. Governability of fisheries and aquaculture: theory and applications. MARE Publication Series, Springer, Berlin, Germany. http://dx.doi.org/10.1007/978-94-007-6107-0

Béné, C. 2009. Food security and poverty alleviation through improved valuation and governance of river fisheries in Africa. Final Report. WorldFish Center, Penang, Malaysia. [online] URL: http://www.worldfishcenter.org/resource centre/WF 2976.pdf

Béné, C., E. Belal, M. O. Baba, S. Ovie, A. Raji, I. Malasha, F. Njaya, M. N. Andi, A. Russell, and A. Neiland. 2009. Power struggle, dispute and alliance over local resources: analyzing 'democratic' decentralization of natural resources through the lenses of Africa inland fisheries. World Development 37:1935-1950. http://dx.doi.org/10.1016/j.worlddev.2009.05.003

Benson, D., A. K. Gain, and J. J. Rouillard. 2015. Water governance in a comparative perspective: from IWRM to a 'nexus' approach? Water Alternatives 8(1):756-773.

Berkes, F. 2009. Evolution of co-management: role of knowledge generation, bridging organizations and social learning. Journal of Environmental Management 90(5):1692-1702. http://dx.doi. org/10.1016/j.jenvman.2008.12.001

Biggs, R., M. Schlüter, and M. L. Schoon, editors. 2015. Principles for building resilience: sustaining ecosystem services in socialecological systems. Cambridge University Press, Cambridge, UK. http://dx.doi.org/10.1017/cbo9781316014240

Biggs, R., F. R. Westley, and S. R. Carpenter. 2010. Navigating the back loop: fostering social innovation and transformation in ecosystem management. Ecology and Society 15(2):9. http://dx. doi.org/10.5751/es-03411-150209

Burns, D. 2007. Systemic action research: a strategy for whole system change. Policy Press, University of Bristol, Bristol, UK.

Case, P., L. S. Evans, M. Fabinyi, P. J. Cohen, C. C. Hicks, M. Prideaux, and D. J. Mills. 2015. Rethinking environmental leadership: the social construction of leaders and leadership in discourses of ecological crisis, development, and conservation. Leadership 11(4):396-423. http://dx.doi.org/10.1177/1742715015577887 
Cash, D. W., W. N. Adger, F. Berkes, P. Garden, L. Lebel, P. Olsson, L. Pritchard, and O. Young. 2006. Scale and cross-scale dynamics: governance and information in a multilevel world. Ecology and Society 11(2):8. http://dx.doi.org/10.5751/es-01759-110208

Chiu, L. F. 2006. Critical reflection: more than nuts and bolts. Action Research 4(2):183-203. http://dx.doi.org/10.1177/147675$\underline{0306063991}$

Cinner, J. E., T. R. McClanahan, M. A. MacNeil, N. A. J. Graham, T. M. Daw, A. Mukminin, D. A. Feary, A. L. Rabearisoa, A. Wamukota, N. Jiddawi, S. J. Campbell, A. H. Baird, F. A. Januchowski-Hartley, S. Hamed, R. Lahari, T. Morove, and J. Kuange. 2012. Comanagement of coral reef social-ecological systems. Proceedings of the National Academy of Sciences of the United States of America 109:5219-5222. http://dx.doi. org/10.1073/pnas.1121215109

Cohen, P. J., J. Cinner, and S. Foale. 2013. Fishing dynamics associated with periodically harvested marine closures. Global Environmental Change 23(6):1702-1713. http://dx.doi.org/10.1016/ j.gloenvcha.2013.08.010

Cohen, P. J., L. S. Evans, and M. Mills. 2012. Social networks supporting governance of coastal ecosystems in Solomon Islands. Conservation Letters 5(5):376-386. http://dx.doi.org/10.1111/ j.1755-263X.2012.00255.X

Cohen, P. J., S. Lawless, M. Dyer, M. Morgan, E. Saeni, H. Teioli, and P. Kantor. 2016. Understanding adaptive capacity and capacity to innovate in social-ecological systems: applying a gender lens. Ambio 45(S3):309-321. http://dx.doi.org/10.1007/ s13280-016-0831-4

Cohen, P. J., and D. J. Steenbergen. 2015. Social dimensions of local fisheries co-management in the Coral Triangle. Environmental Conservation 42:278-288. http://dx.doi.org/10.1017/ $\underline{\mathrm{S} 0376892914000423}$

Colfer, C. J. P., E. Andriamampandry, S. Asaha, I. Basuki, A. Boucard, L. Feintrenie, V. Ingram, M. Roberts, T. Sunderland, and Z. L. Urech. 2011. Minefields in collaborative governance. Pages 233-270 in C. J. P. Colfer, and J.-L. Pfund, editors. Collaborative governance of tropical landscapes. Earthscan, Oxon, UK.

Crow, B., and F. Sultana. 2002. Gender, class, and access to water: three cases in a poor and crowded delta. Society \& Natural Resources 15:709-724. http://dx.doi.org/10.1080/08941920290069308

de Silva S. 2014. Institutional profiles from the Tonle Sap lake region: findings from informant interviews. CGIAR Research Program on Aquatic Agricultural Systems. WorldFish Center, Penang, Malaysia. [online] URL: http://www.worldfishcenter. org/content/institutional-profiles-tonle-sap-lake-region-findingsinformant-interviews

Dewan, C., M.-C. Buisson, and A. Mukherji. 2014. The imposition of participation? The case of participatory water management in coastal Bangladesh. Water Alternative 7 (2):342-366. [online] URL: http://www.water-alternatives.org/ index.php/alldoc/articles/vol7/v7issue2/250-a7-2-4/file

Diepart, J. C. 2010. Cambodian peasant's contribution to rural development: a perspective from Kampong Thom Province.
Biotechnologie, Agronomie, Société et Environnement 14 (2):321-340.

Douthwaite, B., M. Apgar, A.-M. Schwarz, C. McDougall, S. Attwood, S. S. Sellamuttu, and T. Clayton. 2015. Doing Research in Development: Lessons Learned from AAS. CGIAR Research Program on Aquatic Agricultural Systems. WorldFish Center, Penang, Malaysia.

Emerson, K., T. Nabatchi, and S. Balogh. 2012. An integrative framework for collaborative governance. Journal of Public Administration Research and Theory 22(1): 1-29. http://dx.doi. org/10.1093/jopart/mur011

Evans, L., N. Cherrett, and D. Pemsl. 2011. Assessing the impact of fisheries co-management interventions in developing countries: a meta-analysis. Journal of Environmental Management 92:1938-1949. http://dx.doi.org/10.1016/j.jenvman.2011.03.010

Evans, L. S., C. C. Hicks, P. J. Cohen, P. Case, M. Prideaux, and D. J. Mills. 2015. Understanding leadership in the environmental sciences. Ecology and Society 20(1): 50. http://dx.doi.org/10.5751/ es-07268-200150

Foale, S., and M. Macintyre. 2000. Dynamic and flexible aspects of land and marine tenure at West Nggela: implications for marine resource management. Oceania 71(1):30-45. http://dx.doi. org/10.1002/j.1834-4461.2000.tb02722.x

Gain, A. K., and M. Schwab. 2012. An assessment of water governance trends: the case of Bangladesh. Water Policy 14 (5):821-840. http://dx.doi.org/10.2166/wp.2012.143

Govan, H., A.-M. Schwarz, D. Harohau, J. Oeta, G. Orirana, and B. D. Ratner. 2013. Solomon Islands: essential aspects of governance for Aquatic Agricultural Systems in Malaita Hub. Project Report: AAS-2013-19. CGIAR Research Program on Aquatic Agricultural Systems, Penang, Malaysia.

Griggs, D., M. Stafford-Smith, O. Gaffney, J. Rockström, M. C. Öhman, P. Shyamsundar, W. Steffen, G. Glaser, N. Kanie, and I. Noble. 2013. Policy: sustainable development goals for people and planet. Nature 495(7441):305-307. http://dx.doi.org/10.1038/495305a

Hoppe, B., and C. Reinelt. 2010. Social network analysis and the evaluation of leadership networks. Leadership Quarterly 21 (4):600-619. http://dx.doi.org/10.1016/j.leaqua.2010.06.004

Kabeer, N. 2012. Women's economic empowerment and inclusive growth: labour markets and enterprise development. SIG Working Paper 2012/1. Department for International Development, London, UK and International Development Research Centre, Ottawa, Ontario, Canada. [online] URL: http://www.idrc.ca/EN/ Documents/NK-WEE-Concept-Paper.pdf

Kantor, P., and M. Apgar. 2013. Transformative change in the CGIAR research program on aquatic agricultural systems. Program Brief: AAS-2013-25. CGIAR Research Program on Aquatic Agricultural Systems, Penang, Malaysia. [online] URL: http://www.worldfishcenter.org/content/transformative-change-cgiarresearch-program-aquatic-agricultural-systems

Kenia, N., and M.-C. Buisson. 2015. How successful are community-led organizations for water management? Evidence from an assessment of water management organizations in coastal Bangladesh. Pages 131-146 in E. Humphreys, T. P. Tuong, 
M.-C. Buisson, I. Pukinskis, and M. Phillips, editors. Proceedings of the CPWF, GBDC, WLE Conference on Revitalizing the Ganges Coastal Zone: turning science into policy and practices, Dhaka, Bangladesh, 21-23 October 2015. CGIAR Challenge Program on Water and Food (CPWF), Colombo, Sri Lanka.

Kesby, M. 2005. Re-theorising empowerment-throughparticipation as a performance in space: beyond tyranny to transformation. Signs: Journal of Women in Culture and Society 30(4):2037-2065. http://dx.doi.org/10.1086/428422

Keskinen, M., M. Kakonen, P. Tola, and O. Varis. 2007. The Tonle Sap lake, Cambodia: water-related conflicts with abundance of water. Economics of Peace and Security Journal 2(2):9-59. http:// dx.doi.org/10.15355/epsj.2.2.49

Keskinen, M., and S. Sithirith. 2009. Tonle Sap lake and its management: the diversity of perspectives \& institutions. Mekong Water Allocation Project's (PN67) Studies, Siem Reap, Cambodia. [online] URL: http://www.academia.edu/3718631/ Tonle Sap Lake and its management the diversity of perspectives and institutions

Keskinen, M., and O. Varis. 2012. Institutional cooperation at a basin level: for what, by whom?: Lessons learned from Cambodia's Tonle Sap lake. Natural Resources Forum 36(1):50-60. http://dx.doi.org/10.1111/j.1477-8947.2012.01445.x

Kingdon, J. W. 1995. Agendas, alternatives and publics policies. Second edition. Harper Collins, New York, New York, USA.

Kooiman, J., M. Bavinck, R. Chuenpagdee, R. Mahon, and R. Pullin. 2008. Interactive governance and governability: an introduction. Journal of Transdisciplinary Environmental Science 7(1):1-11. [online] URL: http://dare.uva.nl/document/2/59200

Kooiman, J., M. Bavinck, S. Jentoft, and R. Pullin. 2005. Fish for life: interactive governance for fisheries. University of Amsterdam Press, Amsterdam, The Netherlands. http://dx.doi. org/10.5117/9789053566862

Lebel, L., J. M. Anderies, B. Campbell, C. Folke, S. HatfieldDodds, T. P. Hughes, and J. Wilson. 2006. Governance and the capacity to manage resilience in regional social-ecological systems. Ecology and Society 11(1):19. http://dx.doi.org/10.5751/ es-01606-110119

Longley, C., F. Kruijssen, J. Armstrong, N. Phiri, G. Chisule, N. Mundia, M. Amukena, F. Nasilele, N. Jahan, C. Pellegrini, J. Größbrink, C. Muyaule, S. Rajaratnam, E. Madzudzo, and A. Chilala. 2016. Fish value chain analysis and development in the Barotse Floodplain of western Zambia: towards a research in development approach. Working Paper: AAS-2016-04. CGIAR Research Program on Aquatic Agricultural Systems, Penang, Malaysia.

Madzudzo, E., A. Mulanda, J. Nagoli, J. Lunda, and B. D. Ratner. 2013. A governance analysis of the Barotse Floodplain system, Zambia: identifying obstacles and opportunities. CGIAR Research Program on Aquatic Agricultural Systems. WorldFish Center, Penang, Malaysia. [online] URL: http://www.worldfishcenter. org/content/governance-analysis-barotse-floodplain-system-zambiaidentifying-obstacles-and-opportunities

McDougall, C., and M. R. Banjade. 2015. Social capital, conflict, and adaptive collaborative governance: exploring the dialectic. Ecology and Society 20(1):44. http://dx.doi.org/10.5751/ es-07071-200144

Meijerink, S., and D. Huitema. 2010. Policy entrepreneurs and change strategies: lessons from sixteen case studies of water transitions around the globe. Ecology and Society 15(2):21. http:// dx.doi.org/10.5751/es-03509-150221

Middleton, C., and P. Tola. 2008. Community organizations for managing water resources around Tonle Sap lake: a myth or reality? Pages 149-159 in M. Kummu, M. Keskinen, and V. Olli, editors. Modern myths of the Mekong - a critical review of water and development concepts, principles and policies. Water \& Development Publications, Helsinki University of Technology, Espoo, Finland.

Molle, F., L. Lebel, and T. Foran. 2010. Contested Mekong waterscapes: Where to next? Pages 383-413 in F. Molle, T. Foran, and M. Kakonen, editors. Contested waterscapes in the Mekong Region: hydropower, livelihoods and governance. Earthscan, London, UK and Institute for Southeast Asian Studies, Singapore.

Mwangi, E., and D. A. Wardell. 2012. Multi-level governance of forest resources. International Journal of the Commons 6 (2):79-103. http://dx.doi.org/10.18352/ijc.374

Naz, F., and M.-C. Buisson. 2015. Multiple actors, conflicting roles and perverse incentives: the case of poor operation and maintenance of coastal polders in Bangladesh. Pages 147-161 in E. Humphreys, T. P. Tuong, M.-C. Buisson, I. Pukinskis, M. Phillips. Proceedings of the CPWF, GBDC, WLE Conference on Revitalizing the Ganges Coastal Zone: turning science into policy and practices, Dhaka, Bangladesh, 21-23 October 2015. CGIAR Challenge Program on Water and Food (CPWF), Colombo, Sri Lanka.

Newig, J., D. Günther, and C. Pahl-Wostl. 2010. Synapses in the network: learning in governance networks in the context of environmental management. Ecology and Society 15(4):24. [online] URL: http://www.ecologyandsociety.org/vol15/iss4/ art24/

Nurick R., and M. Apgar. 2014. Participatory action research: guide for facilitators. CGIAR Research Program on Aquatic Agricultural Systems. WorldFish Center, Penang, Malaysia. [online] URL: http://www.worldfishcenter.org/content/participatoryaction-research-guide-facilitators

Ojha, H. R., A. Hall, and R. Sulaiman V. 2013. Adaptive collaborative approaches in natural resource governance. Earthscan, Oxon, United Kingdom.

Olsson, P., C. Folke, and T. P. Hughes. 2008. Navigating the transition to ecosystem-based management of the Great Barrier Reef, Australia. Proceedings of the National Academy of Sciences of the United States of America 105(28):9489-9494. http://dx.doi. org/10.1073/pnas.0706905105

Olsson, P., L. H. Gunderson, S. R. Carpenter, P. Ryan, L. Lebel, C. Folke, and C. S. Holling. 2006. Shooting the rapids: navigating transitions to adaptive governance of social-ecological systems. Ecology and Society 11(1):18. http://dx.doi.org/10.5751/ es-01595-110118 
Ostrom, E. 2005. Understanding institutional diversity. Princeton University Press, Princeton, New Jersey, USA.

Ostrom, E. 2009. A general framework for analyzing sustainability of social-ecological systems. Science 325 (5939):419-422. http://dx.doi.org/10.1126/science.1172133

Pahl-Wostl, C. 2009. A conceptual framework for analysing adaptive capacity and multi-level learning processes in resource governance regimes. Global Environmental Change 19:354-365. http://dx.doi.org/10.1016/j.gloenvcha.2009.06.001

Pahl-Wostl, C., M. Craps, A. Dewulf, E. Mostert, D. Tabara, and T. Taillieu. 2007. Social learning and water resources management. Ecology and Society 12(2):5. http://dx.doi. org/10.5751/es-02037-120205

Pahl-Wostl, C., G. Holtz, B. Kastens, and C. Knieper. 2010. Analysing complex water governance regimes: the management and transition framework. Environmental Science \& Policy 13 (7):571-581. http://dx.doi.org/10.1016/j.envsci.2010.08.006

Patton, M. 1990. Qualitative evaluation and research methods. SAGE, Thousand Oaks, California, USA.

Pelling, M. 2010. Adaptation to climate change: from resilience to transformation. Routledge, London, UK.

Phelps, R., and S. Hase. 2002. Complexity and action research: exploring the theoretical and methodological connection. Educational Action Research 10(3):507-524. http://dx.doi. org/10.1080/09650790200200198

Pomeroy, R. S. 1995. Community-based and co-management institutions for sustainable coastal fisheries management in Southeast Asia. Ocean \& Coastal Management 27(3):143-162. http://dx.doi.org/10.1016/0964-5691(95)00042-9

Popplewell, R., and R. Hayman. 2012. Where, how, and why are action research approaches used by international development non-governmental organisations? Briefing Paper 32. INTRAC, Oxford, UK.

Ratner, B. D., P. Cohen, B. Barman, K. Mam, J. Nagoli, and E. H. Allison. 2013b. Governance of aquatic agricultural systems: analyzing representation, power, and accountability. Ecology and Society 18(4):59. http://dx.doi.org/10.5751/ES-06043-180459

Ratner, B. D., R. Meinzen-Dick, C. May, and E. Haglund. $2013 a$. Resource conflict, collective action, and resilience: an analytical framework. International Journal of the Commons 7(1):183-208. http://dx.doi.org/10.18352/ijc. 276

Reason, P. 2006. Choice and quality in action research practice. Journal of Management Inquiry 15(2):187-203. http://dx.doi. org/10.1177/1056492606288074

Reason, P., and H. Bradbury, editors. 2008. The SAGE handbook of action research: participative inquiry and practice. Second edition. SAGE, Thousand Oaks, California, USA. http://dx.doi. org/10.4135/9781848607934

Reason, P., and W. R. Torbert. 2001. The action turn: toward a transformational social science. Concepts and Transformation 6 (1):1-37. [online] URL: https://dlib.bc.edu/islandora/object/bcir:100482/datastream/PDF/download/citation.pdf
Resurreccion, B. P. 2006. Rules, roles and rights: gender, participation and community fisheries management in Cambodia's Tonle Sap region. International Journal of Water Resources Development 22(3): 433-447. http://dx.doi. org/10.1080/07900620500482949

Ribot, J. C. 1999. Decentralization, participation and accountability in Sahelian forestry: legal instruments of politicaladministrative control. Africa 69(1):23-65. http://dx.doi. org/10.2307/1161076

Roberts, G., and B. Dick. 2003. Emancipatory design choices for action research practitioners. Journal of Community and Applied Social Psychology 13(6):486-495. http://dx.doi.org/10.1002/ casp. 753

Rom, R. B. 1998. 'Safe spaces': reflections on an educational metaphor. Journal of Curriculum Studies 30(4):397-408. http://dx. doi.org/10.1080/002202798183549

Scheffer, M., F. Westley, and W. Brock. 2003. Slow response of societies to new problems: causes and costs. Ecosystems 6 (5):493-502. http://dx.doi.org/ 10.1007/PL00021504

Song, A. M., R. Chuenpagdee, and S. Jentoft, 2013. Values, images, and principles: what they represent and how they may improve fisheries governance. Marine Policy 40:167-175. http:// dx.doi.org/10.1016/j.marpol.2013.01.018

Westley, F., P. Olsson, C. Folke, T. Homer-Dixon, H. Vredenburg, D. Loorbach, J. Thompson, M. Nilsson, E. Lambin, J. Sendzimir, B. Banerjee, V. Galaz, and S. van der Leeuw. 2011. Tipping toward sustainability: emerging pathways of transformation. Ambio 40 (7):762-780. http://dx.doi.org/10.1007/s13280-011-0186-9

Westley, F. R., O. Tjornbo, L. Schultz, P. Olsson, C. Folke , B. Crona, and Ö. Bodin. 2013. A theory of transformative agency in linked social-ecological systems. Ecology and Society 18(3):27. http://dx.doi.org/10.5751/es-05072-180327

Whyte, F. W. 1984. Learning from the field: a guide from experience. SAGE, Thousand Oaks, California, USA.

Wicks, P. G., and P. Reason. 2009. Initiating action research: challenges and paradoxes of opening communicative space. Action Research 7(3):243-262. [online] URL: http://arj.sagepub. com/content/7/3/243.full.pdf+html http://dx.doi. org/10.1177/1476750309336715

Yin, R. K. 2009. Case study research: design and methods (applied social research methods. Fourth edition. SAGE, Thousand Oaks, California, USA. 